\title{
Empiricism in Herbert Simon: Administrative Behavior within the evolution of the Models of Bounded and Procedural Rationality
}

\author{
Empirismo em Herbert Simon: Comportamento \\ Administrativo dentro da evolução dos \\ Modelos de Racionalidade Limitada e Procedural
}

ALEJANDRO HORTAL*

RESUMO: Este artigo contextualiza o livro de Simon, Comportamento Administrativo, na evolução de suas ideias argumentando que o elemento comum que une este livro com o restante do trabalho de Simon não é a crítica da abordagem clássica, mas uma estrutura epistemológica, com base em uma metodologia empírica. Este empirismo é o elemento que permaneceu constante durante sua carreira e levou-o a introduzir fatores psicológicos ao explicar o comportamento dos agentes econômicos sob seus modelos de racionalidade limitada e processual.

PALAVRAS-CHAVE: Herbert A. Simon; racionalidade limitada; racionalidade processual; empirismo.

ABSTRACT: This paper contextualizes Simon's book, Administrative Behavior, within the evolution of his ideas arguing, contrary to what some have posited, that the common element that unites this book with the rest of Simon's work is not the criticism of the classical approach, but an epistemological frame, based on an empirical methodology. This empiricism is the element that remained constant during his career and led him to introduce psychological factors when explaining the behavior of economic agents under his models of bounded and procedural rationality.

KEYWORDS: Herbert A. Simon; bounded rationality; procedural rationality; empiricism. JEL Classification: A11; D01; B52; B31; D21.

\footnotetext{
* Department of Languages, Literatures and Cultures, University of North Carolina at Greensboro and Departmento de Lógica, Historia y Filosofía de la Ciencia, Universidad Nacional de Educación a Distancia (UNED). E-mail: a_hortal@uncg.edu. Submitted: 17/September/2015; Approved: 15/ August/2016.
} 


\section{INTRODUCTION}

In light of the importance that Herbert Simon and his concept of bounded rationality (BR) have been acquiring among behavioral economists in general (Geiger, 2015, p. 2) and, as an example, in regard to nudge theory (Muramatsu and Fonseca, 2012) and other branches of behavioral economics in particular, this paper aims at contextualizing the role of Herbert Simon's book Administrative Behavior $(A B)$, within the framework of the evolution of his ideas. Some authors see in this first work a strong criticism of classical and neoclassical elements. A different position is argued here. Simon's first book, far from being extremely critical and opposed to mainstream economics, did share some of its fundamental ideas. The common element that unites $A B$ with the rest of Simon's work is not the criticism of the classical approach, but an epistemological frame, based on empirical methodology, which contributed in the introduction to psychological factors in the explanation of economic agents. Some authors, like Gustavo Barros, mentioned this disparity (2010, p. 457). This paper adds to that extent that what was constant during his research career and what pushed Simon to a complete rejection of the classical paradigm years later was this philosophical empiricism. This empirical approach, among other factors, was the main foundation of his models of bounded and procedural rationality. Simon's constant use of a positivist approach, not only made him the epicenter of this epistemological viewpoint in public policy (Cruise, 1997), but also helped him to develop other concepts (satisficing, etc.) that eventually introduced a new paradigm in rational theory within the larger context of a behavioral revolution (Mingus, 2007; Geiger, 2015). This new paradigm was yet to be seen in Simon's first book.

In the history of social sciences, economics and management some authors (Dequech, 2001; González, 2004; Brown, 2004; Sent, 2005; Callebaut, 2007, p. 77) have written about the importance of Herbert Simon in criticizing the standard (classical and neoclassical) economic model, even considering him a point of inflexion in how the theory has changed when describing and explaining economic decisions. Many of them pay little or no attention to the evolution of this criticism. Other authors (Barros, 2010) have argued that the first writings of Simon are in line with the neoclassical tradition in economy, as opposed to those written later, which are centered on the idea that neoclassic postulates are unrealistic. The objective of this article is to contextualize $A B$ within the epistemological evolution of his research, analyzing some of the elements of his criticism of mainstream economics that were present then, while shedding light on other elements that were absent. This will clarify the role of his first book within the general scope of his empirical philosophy, the true and constant foundation of his theoretical building that gave birth to the models of bounded and procedural rationality, fundamental premise of behavioral economics.

This concept, which appeared for the first time in his book Models of Man (Simon, 1957) and its parallel concept of "procedural rationality" (Simon, 1976) were coined by Simon to criticize the theory of rationality of neoclassical econom- 
ics, accusing it of being an ideal generalization of how agents really behave. During Simon's extensive research career, these concepts appear and reappear with the same intention and powerful criticism. Considering that Simon's doctoral thesis was published as a book (Simon, 1997 [1947]), the question this article answers is if, in that first book, we can implicitly see the above mentioned model, as Simon himself posits (Simon, 1991, p. 87), or if it would be an anachronism to see such work as the birth of it (Barros, 2010, p. 459).

\section{EMPIRICISM IN HERBERT SIMON}

Although there are elements in $A B$ that depart from the neoclassical tradition, there are also ideas in line with it. The important element that was constant during his career was the empirical frame of his research, that is, his "world view," borrowing Reva Brown's terminology (2004, p. 1246). What we do not find in his first writings is a deep opposition to classical economics. Simon's logical evolution goes from the introduction of empirical methodologies that helped giving birth to his theory of rationality and its limits, to a new alternative model of rationality. In his first book, he challenged parts of mainstream economics, but kept and used some of its central terminology, e.g., "maximization" or the "criterion of efficiency" and premises. It would be in subsequent articles (Simon, 1955, 1956) that he later introduced new concepts and models (satisficing, and administrative man) replacing those belonging to the neoclassical paradigm.

Simon himself (1991, p. 53) and others (Crowther-Heyck, 2005, p. 70; González, 2004, p. 12) noted that one of the most important influences he had as a student at the University of Chicago was the logical positivism of his professor Rudolph Carnap. Such influence can be seen in his doctoral thesis, which started as an attempt to study the logical fundaments of administrative science. The original title of Simon's thesis was The Logical Structure of an Administrative Science.

Carnap's positivism had a long lasting effect in Simon: "I had already embraced a logical positivism that I have never relinquished (I would prefer to call it empiricism now)" (Simon, 1991, p. 44). As Crowther-Heyck explains:

This philosophy was based on the radical empiricism of Ernst March and the formal-logical understanding of mathematics developed by Gottlop Frege, Bertrand Russell, and Alfred North Whitehead. The logical empiricists held that the only things we could know for certain about the world were our sensory experiences of it. $(2005$, p. 71$)$

His philosophical empiricism was already present at the end of the 1930s, when he and other friends interested in epistemology met regularly to discuss different interests and projects always under the umbrella of logical positivism (Simon, 1991, p. 75).

Simon explains in $A B$ that "scientific propositions [...] are statements about 
the observable world and the way in which it operates" (1997 [1947], p. 356); these statements can be classified as "true" or "false," as opposed to ethical statements based on preferences. Observation, therefore, had to be the epistemological epicenter of any research, not only about the physical world, but also about our behavior. Simon's empiricism was never as radical as the one practiced by the above-mentioned philosophers, but he understood the need to integrate the mathematical formalization and empirical testing.

Experimentation was also central for his research, and together with mathematical models, social sciences were not in a position to ignore the actual behavioral processes anymore, for if they wanted to have any scientific status, Simon's epistemology demanded a realistic explanation of human behavior and its processes. This empiricism is one of the reasons why Simon started to analyze behavior as a psychologist: not only looking at the outcomes of decisions, but also the process itself. As Bryan Jones explains, "Simon also developed what he termed a procedural model of rationality, based on the psychological process of reasoning" (Jones, 1999, p. 301). In order to accurately describe economic events, Simon needed the help of psychology. There may be other reasons why Simon introduced psychology within the field of economics (historical, social, biographical, philosophical, etc.), but as Sent pointed out (2004), as part of the old behavioral economics movement, Simon was motivated to find empirical laws in order to describe behavior as accurately as possible. His effort to explain the behavior of agents from a positive perspective was a significant departure from the neo-classical approach: "whereas mainstream economics started from given alternatives and known consequences, old behavioral approaches began with empirical evidence about the shape and content of the utility function" (Sent, 2004, p. 742). Positivism, as expressed and practiced by Herbert Simon, affected the field of public policy for almost 20 years, as Peter Cruise pointed out (1997).

\section{THE NEED FOR PSYCHOLOGY}

Although the collaboration between psychology and economics in Simon was not necessarily forced only by his own empiricism, it is clear that this epistemological approach pushed him, among other contributing factors, to establish this connection (Sent, 2004, p. 739). One of the reasons why Simon looked for the help of psychology was to attach the economic and organization theory about agents to some empirical data.

Relying on the work of Chester Barnard, the objective of $A B$ was to build a vocabulary and a framework to describe, from a psychological and logical point of view, the decision processes of administrative organizations (Simon, 1997 [1947], p. 131). In his autobiography he explained that although $A B$ lies within the classical tradition, it is almost wholly empirical (Simon, 1991, p. 59). This empirical methodology is partially linked to the use of these two disciplines, mainly psychology, to describe the phenomena in organizations. William James (for the tradi- 
tional topics in psychology) and Edward C. Tolman's behaviorism influenced Simon's first work (Simon, 1997 [1947], p. 93n.). Tolman, whose book Purposive Behavior of Animal and Men (1932) included a theory based on means and goals (purposive behaviorism) based on experiments with rats and mazes, especially helped Simon with his instrumental approach to rationality as goal-oriented (Simon, 1991, p. 190). According to Crowther-Hyeck, "this notion of purposeful behavior as being characterized by the selection of alternatives was fundamental, for it provided an avenue for observing the 'choice which prefaces all action'. Choice, understood as decision-making, would be the keystone for the reconstruction of administrative science" (2005, p. 102). When Simon introduced the topic of rationality in chapter IV of $A B$, he described choice as a cognitive rational decision under an instrumental framework. Therefore, once psychology became part of the investigation, he also had to admit that humans did not always follow the rational predicament. This statement, as he recognized (Simon, 1997 [1947], p. 72), contradicted a large part of the classical and neoclassical economic theory.

It is important to point out that Simon worked in the department of psychology at Carnegie Mellon University, and some consider him the founder of the information processing approach to cognitive psychology (Kotovsky, 1989, p. xvi.) Empiricism was one of the most significant factors that led Simon to embrace psychology and the analysis of behavioral processes. Once the psychological methodology was adopted, Simon's most important concepts started to appear in the structure of its models and theories -bounded rationality, satisfice, and procedural rationality: "cognitive psychology has established the robust empirical finding that human rationality is inherently bounded by innate, insuperable limitations on information processing" (Weyland, 2007, p. 45).

The field of administrative science was in need of a better methodology that increased its scientific status. This methodology, according to Simon (1991, p. 73), had to include systematic observations and experimentation. In 1946 he wrote a preface to the first edition in which he argued for an experimental approach to administrative science (Simon, 1997 [1947], p. xi). In order to successfully pursue research on this subject, according to Simon, an experimental control was needed in order to isolate the effects studied (1997 [1947], p. 48).

\section{THE PROBLEMATIC VALUE ELEMENTS}

An administrative science had to be based on factual elements and had to produce factual statements. Since decisions, as part of the research within administrative science, had a value and a fact component, the value component had to be left out of the scope of scientific research because its propositions could not be "objectively described as correct or incorrect" (Simon, 1997 [1947], p. 56). Value elements for Simon were important, but due to epistemological requirements and in direct contradiction to the work of Barnard (Cruise, 1997, p. 352), they had to be outside of the theory, leaving us with an instrumental understanding of rational- 
ity (Álvarez Álvarez, 2002) under a means-end schema. Simon himself recognized the limitations of such approach (1997 [1947], p. 75) stressing, not only the importance of the value questions in the means employed but also how insufficient this was as a full description of decisions (Crowther-Heyck, 2005, p. 112).

The empiricism of Simon's first book is not a matter of dispute. What requires consideration is the presence of a strong criticism of classical economics there. What we find instead is a weak criticism of the classical economics postulate that humans are always or generally rational. "That misconception $[. .$.$] has been decisively re-$ futed by modern developments in psychology and sociology" (Simon, 1997 [1947], p. 72).

As noted by Crowther-Heyck (2005, p. 101), the application of empiricism to social sciences had an important problem: the human mind. With the use of psychology, the influence of Tolman's purposive behavior and the use of concepts like cognition or purpose, which Simon defined as docility (Crowther-Heyck, 2005, p. 102), he was able to navigate through administrative science using an empirical epistemology. According to Crowther-Heyck, he created a "true science" by considering human behavior as operational (selection of behavior alternatives). Simon found his observable element in human choices, which are considered as decisions, without having a clear difference (Simon, 1997 [1947], p. 3).

\section{BOUNDED AND PROCEDURAL RATIONALITY}

In Models of Man (1957, p. 198) Simon introduced the concept "bounded rationality" for the first time. Nineteen years later he would use the term "procedural rationality" (Simon, 1976). That last term, epicenter of his empirical methodology, although not explicitly present in his first book, was implicitly used. $A B$ is essential to understand his theory, not because we see in this book his most important concepts, but because with it, Simon puts in motion some of the elements that took him to the deepest criticism of mainstream economics, which did not fully happen until the late 1950s, with the introduction of concepts such as "administrative man", "satisfice", "bounded rationality" and, in the 1970s, with the introduction of the term "procedural rationality", coined in order to describe aspects of his theory that were present before.

His empiricism, partially connected to the use of psychology, also influenced him to look at the process of election, more than the outcome itself: procedural rationality "as it is empirically-grounded, it captures the real cognitive capacities of people, i.e., the bounded aspect underlined by the 'costly rationality' conception. But it goes further than this conception. The procedural aspect characterizes the presence of deliberation in the process of choice. The choice conditions are not given to the decision-maker, but are the subjects of a search process. As people are not assumed to know all future situations, alternatives and their consequences, the search, the evaluation and the ranking of the various possible actions stem from a deliberation process" (Chaserant, 2003, p. 166). 
Simon's empiricism, among other factors, helped him to accept certain limits of rationality, but his goal then was just to call attention to some limitations of the economic theory, without proposing a new model. The alternative model arrived later, as mentioned above. $A B$, therefore, is the initial criticism, a negative exposure of the epistemological limitations of a theory, but not a constructive criticism. There is a fundamental connection between Simon's empiricism the new model of rationality, an empiricism that was already present from the beginning and a foundation for his entire career. Although Subrata Dasgupta, for example, already mentioned Simon's commitment to empiricism (2003, p. 687), The author did not emphasize enough its importance in the development of the different concepts and theories coined by Simon.

The first steps in the evolution of Simon's theory, from his partial defense of some neoclassical elements, to his rupture with the mainstream model in economics, started with the criticism of the "linguistic and conceptual tools" (Simon, 1997 [1947], p. xi) of the standard administration theory. On his journey he revised the description of human decisions proposing a different model of rationality and an alternative model to understand economic behavior and decisions.

On the one hand, we had a "classical" Herbert Simon who used an instrumental idea of rationality, suffered from a rationalistic bias, and supported the idea that the objective of any organization was to maximize according to the criterion of efficiency, recognized by neoclassical theory as profit maximization or cost minimization; on the other hand, he accepted that humans were not always rational, and that such rationality had limits (Simon, 1997 [1947], p. 45). As Joseph Mahoney explains:

Simon is consistent with the logic of economics and uses the familiar language of information, efficiency, implementation, and design. Unlike neoclassical economics, however, Simon also insists on coming to terms with cognitive limitations, which are discussed in terms of constraints, authority, routines... $(2004$, p. 6$)$

What is relevant for Simon's future theory of rationality is the empirical approach to the distinction between factual and value decisions. Only factual decisions can be falsified; value decisions can be good, but they cannot be described as correct or incorrect. Simon's empiricism demanded an instrumental version of rationality similar to the concept of efficiency. This concept is the fabric of his (meansend) instrumental view of rationality in $A B$, since to be efficient is to "take the shortest path, the cheapest means, toward the attainment of the desired goals" (Simon, 1997 [1947], p. 12). As Davis claims (1996), Simon's concept of rational is equivalent to efficient, so organizational rationality is economic efficiency. An efficient individual is someone "that attempts rationally to maximize the attainment of certain ends with the use of scarce means" (Simon, 1997 [1947], p. 45).

Simon's empiricism required an approach to rationality based on the falsifiable and measurable concept of efficiency under the means-end schema. The outcome 
is the instrumental view of rationality, rejecting any other value proposition due to their lack of scientific status.

As Robert Bartlett $(1989$, p. 306) indicated, Simon's first work starts with a classical economics definition of rationality as an attribute of behavior. To this classical rationality some limitations were added (produced by Simon's empirical requirements). Simon is using both a substantive rationality (when is appropriate to the achievement of goals within limits) and a procedural approach (outcome of a deliberation, process of choice) without clarifying their differences, which did not happen (Bartlett, 1989, p. 307) until 1964 in A Dictionary of Social Sciences. Until that moment Simon kept using a version of substantive rationality, parallel to the implicit use of a procedural approach to rationality, since its scientific status was extremely high: substantive rationality neglected all types of internal psychological factors and focused only on the external environment (Bonome, 2010, p. 31) when explaining rationality. This provided an approach close to the one we practiced in Physics.

In the subsequent writings Simon clarified his position and, in 1976, he clearly classified both conceptions in his article From Substantive to Procedural Rationality. Substantive rationality was originated in the economics field and procedural came from psychology.

In an attempt to describe and explain all factors that intervene in rationality Simon had to attend to those from our "mind" as they were connected to the environment (Simon, 1956). Procedural rationality provided that type of insight. When Simon classified substantive rationality as a form of global (perfect) rationality that neglected the psychological processes involved in rational decisions, he associated the term with the classical and neoclassical traditions in economics. Once the limitations of rationality were considered and the model of bounded rationality well established, as it was in 1976, Simon coined the term of procedural rationality to refer to the concept developed within psychology related to the rational activity "when it is the outcome of appropriate deliberation".

Although efficiency is considered part of the instrumental terminology in Simon's $A B$, it is also a concept that manifests the implicit use of procedural rationality is his theory. The search for efficiency can be seen as the search for procedural rationality (Simon, 1976, p. 133), since this concept relates to our ability to find “appropriate adaptive behavior" (Bartlett, 1989, p. 308) through our cognitive capabilities.

Simon's 1976 article already incorporates other parts of his theory into the concept of procedural rationality: bounded rationality, satisficing, and the criticism against classical and neoclassical economics and perfect rationality are all interrelated in the construction of the above-mentioned concept. In $A B$, Simon did not use the term "procedural rationality," but he did in fact apply its methodology by looking at the process of thought and psychological factors that affected rationality within the organizational frame. The concept of efficiency is an example: "most of Simon's discussions of efficiency relate to his critique of neoclassical substantive rationality, which offers a standard against which behavior can be judged" (Bartlett, 1989, p. 309). 


\section{INSTRUMENTAL RATIONALITY}

The instrumental approach is the default (Nozick, 1993, p. 133) theory of rationality and it is the only one that does not need justification (but it is not the only theory). For Simon, reason is entirely instrumental (Callebaut, 2007, p. 80). His definition of rationality as it is given in his first book was conceived under a means-end frame: "rationality is correct if it selects appropriate means to reach designated ends" (Simon, 1997 [1947], p. 72). A few years later, in 1964, in an article he wrote for a dictionary of the Social Sciences, the concept had not changed much: "In a broad sense, rationality denotes a style of behavior (A) that is appropriate to the achievement of given goals (B) within the limits imposed by given conditions and constraints" (Simon, 1982, p. 405).

As mentioned above, we can trace the psychological origins of Simon's instrumental conception of rationality in Tolman's behaviorism, but its philosophical roots are placed, according to Nieuwenburg (2006, p. 89), in David Hume (never mentioned by Simon) through Alfred Ayer, whose influence was recognized by $\mathrm{Si}-$ mon himself (1997 [1947], p. 55n).

From a general perspective, Simon's objective was to explain rationality from a realistic point of view. This empirical methodology caused him, in $A B$, to accept specific limits within rational processes (1997 [1947], p. 45) accusing, therefore, the classical theory of the firm of not giving any explanation for them. The introduction of these limits was in part due to the fact that Simon looked at the rational process, more than the outcome itself, in explaining how agents and firms operate. This analysis of procedures was the first step of what later would be his "procedural rationality".

His desire for a realistic (empirical) explanation of the theory of the firm pushed him to look at the procedures of how agents decide, admitting certain limits that affected the level of efficiency desired by a single member of an organization. The way Simon linked "limits" with "efficiency" denoted a connection with an instrumental understanding of rationality: reason cannot select final goals; it only tells how to reach them (Simon, 1983, p. 106). But an instrumental rationality theory does not necessarily imply the rejection of a methodology based on the study of rational processes. In Simon's first book we find a first version of what he eventually denominates "procedural rationality" that is not only instrumental, but also considers the cost of acquiring information to arrive to an optimal course of action (or a satisfactory one). Hargreaves Heap referred to it as the "procedural version of instrumental rationality" (Heap et al., 1992, p. 4). The idea of having an instrumental rationality that incorporated "satisfaction" as explained by Michael Byron (1998), is the "satisficing conception of instrumental rationality": we do not need to choose the best means to arrive to our goals. 


\section{THE CLASSICAL ELEMENTS OF $A B$ : MAXIMIZATION AND EFFICIENCY}

Herbert Simon's concept of rationality in his first book was drawn between two ideas: the need to be efficient (criterion of efficiency) and the limits to achieve it. Maximization was still the objective: "this maximization is the aim of administrative activity, and that administrative theory must disclose under what conditions the maximization takes place" (Simon, 1997 [1947], p. 45). Simon's criterion of efficiency selects which alternative produces the largest result according to our resources, and it can be seen, as he himself explains, analogous to the concept of maximization of utility (1997 [1947], p. 258). Simon clarified that such criterion did not always dominate the behavior of administrators; it would only if they were rational, it would. This type of rationality was not a common characteristic of human behavior; in fact, he criticized mainstream economics in that same paragraph for using this model to describe and explain behavior in the market. Efficiency was seen by Simon as a way to clarify that if two results can be achieved with the same cost, the greater result is to be preferred.

Simon's chapter IX of $A B$ was an account of the criterion of efficiency and a refutation of its criticisms. While supporting it, he also introduced the aspect of valuation into the process denying a ruthless, mechanical, and Machiavellian (the ends justifying the means) interpretation of such criterion (1997 [1947], pp. 259-260), but he placed this valuation outside of science, arguing that "the adaptation of means to ends is the only element of the decisional problem that has a factual solution" (1997 [1947], p. 260). Simon noted that this was not an excuse to eliminate the importance of valuation, admitting that to consider administrative activity free from valuation was just an "abstraction from reality which is permissible", but cannot be carried to extremes.

Accepting valuation was not a form of expressing an alternative view of rationality (expressive or axiological), but simply a statement acknowledging that, in decision theory, we have value and factual elements (Simon, 1997 [1947], p. 55). He was not accepting some type of axiological rationality as Boudon (1998) does. As a social scientist, Simon wanted to have empirical (factual) information about the decision processes involved in behavior and that was epistemologically easier with the criterion of efficiency. Every decision contains an ethical element that is the expression of a preference involving a motivational state; therefore, "reasons for actions are always dependent on the presence of certain desires in the psychology of those who are to perform those actions" (Nieuwenburg, 2006, p. 90).

In $A B$, rationality was fully instrumental, and maximization (through the criterion of efficiency), although difficult to achieve due to certain limits, was the goal of any firm. Maximization, therefore, was admitted as a possibility, and not as an ideal and unrealistic goal. Efficiency had to have a level that corresponded with the limitations described by the theory. Around half a century later Thomas Sargent (1993) will propose a theory of rational limits similar to that of Herbert Simon's first book, based on maximization under constraints. As a sign of his evolution 
against the rational approach of mainstream economics, Simon himself would later criticize this theory (Callebaut, 2007). Sargent, an advocate of the rational expectations theory, introduced limits of rationality but kept the ideal of optimization (Gigerenzer, 2004, p. 391). Simon's first work and the work of Sargent are similar in the sense that although constraints are admitted, the ideal of maximization had not been fully rejected and a new alternative approach had not yet been proposed. Simon calls this type of rationality in his first book "subjective rationality", which "maximizes attainment relative to the actual knowledge of the subject" (Simon, 1997 [1947], p. 85). Sargent's bounded rationality was similar to that of the early Simon but radically different from the later Simon, when the alternative model of rationality was fully developed. Sargent's approach to the limits of rationality was neoclassical because through learning, he attempted to reestablish the symmetry among subjects: "Sargent tried to link his interpretations of bounded rationality and artificial intelligence with those of Simon. This link turned out to be rather weak. Since Sargent wanted to restore symmetry by incorporating learning, he embraced neoclassical theory" (Sent, 1997, p. 335).

Dwight Waldo (1948, p. 202) also criticized efficiency as a normative approach. In reference to an article written by Simon and Ridley (1938), he expressed his discomfort and denounced that the value of efficiency was just a "mirage", an ideal. It would be unfair to describe Simon's concept of efficiency in $A B$ as an idealization similar to those he later censured. Nor was it a concept that could have emerged from an empirical approach but from a normative wish where "over-all efficiency must be the guiding criterion" (Simon, 1997 [1947], p. 43). Good behavior, for a firm, could be defined as that criterion of efficiency: it did not express how to obtain maximization but just that maximization was the aim of any organization, and administrative theory the one explaining "under what conditions the maximization takes place" (Simon, 1997 [1947], p. 45). Maximization existed in the early Simon, but it was affected by specific limits that could be exposed under a procedural analysis of rationality.

In $A B$ Simon started to look at the process (procedural) of decision making, arriving at the conclusion that rationality was not as perfect as what is described in classical economics. Simon's rationality model took these imperfections into consideration, but it was not until later that Simon introduced an alternative model of rationality opposite to that postulated by mainstream economics. His alternative model had to wait until the appearance of his two seminal articles about these issues (Simon, 1955, 1956): the inclusion of cognitive processes and limits in rationality, and the addition of the term "bounded rationality" (1957). Only at that moment did he fully reject the classical and neoclassical ideals of maximization and global rationality by proposing a new paradigm. His theory then became a true alternative and not a mere modification to the one postulated by the previous economic frame. We can see in Simon an evolution in his criticism of mainstream economics that goes from accepting parts of it (i.e., maximization) to the proposal of a new model. 


\section{THE EVOLUTION TOWARDS THE MODELS OF BOUNDED AND PROCEDURAL RATIONALITY}

The most important element that started to appear from his first writings and remained throughout Simon's career was the empirical methodology that led him to the concept of "procedural rationality" (Simon, 1976). Some authors (Barros, 2010 ) even argue that this concept is much more powerful than bounded rationality, which they define as a negative concept that emanates as a criticism to the global rationality model of mainstream economics. Although not explicitly mentioned in $A B$, Simon used a classical version of procedural rationality under an instrumental frame. While we may consider procedural a form of rationality different from the one used by mainstream economics, Hargreaves Heap (1992, p. 4) explains that this type can also be a version of instrumental rationality since it allows actions to be guided by procedures in order to satisfice (instead of maximizing) a decision towards a specific goal. This procedural instrumental rationality is the one present in Simon's first book, though not fully elaborated. It will be entirely defined and integrated in Simon's model almost 30 years after the publication of his doctoral dissertation with the paper From Substantive to Procedural Rationality (1976). In this article, he juxtaposed substantive and procedural rationality, classifying the first as originated in the core of economics: "I shall use the phrase 'substantive rationality' to refer to the concept of rationality that grew up within economics, and 'procedural rationality' to refer to the concept that developed within psychology [...] Behavior is substantively rational when it is appropriate to the achievement of given goals within the limits imposed by given conditions and constraints" (Simon, 1976, p. 130). Simon linked his definition of substantive rationality with the achievement of goals considering limitations. This substantive rationality is equivalent to the rationality model of Thomas Sargent in Bounded Rationality in Macroeconomics (1993) and, therefore, to some versions of rationality posited by Simon in his doctoral dissertation. According to Simon, the reason why neoclassical economics embraced a substantive theory of rationality was its lack of empirical methodology (1997, p. 369), neglecting the observation and explanation of any process of deliberation in decisions. The evolution of Simon's theory on rationality can be traced as follows:

1. 1947: Limits of rationality, maximization under constraints (similar to Sargent's model which he later criticized), and criterion of efficiency

2. 1955-1956: Satisficing instead of maximizing.

3. 1957: Introduction of "bounded rationality" as a term referred to the model introduced the previous years.

4. 1976: appearance of the concept "procedural rationality" to provide terminological depth to the alternative model of rationality.

The constant application of his empirical methodology is what took Simon from point 1 to 4 in proposing a new rationality paradigm in social sciences. His 
philosophical empiricism was the cement that glued the different bricks of his theoretical building and is at the foundation of his rational model based on the concept of "procedural rationality", which logically (not historically) precedes "bounded rationality".

Since in his first book he had not fully developed the new model of rationality and was embracing some classical concepts, there were no clear differences between procedural and substantive rationality in it: behavior in this first book is rational when it is appropriate to the achievement of given goals within certain limits. Using his own terminology from 1976, Simon's rationality was a matrix of substantive and procedural elements. To this end, the criterion of efficiency can be classified under the substantive row, while the different limits listed by Simon in chapter II of his first book (1997 [1947], p. 45) could be placed under the procedural column. With the inclusion of other elements within Simon's theory in the following years, the substantive row eventually disappeared, but not his instrumental approach.

Herbert Simon's instrumental view of rationality was permanent during his research years and the need to introduce different forms of rationality has been broadly stressed by many (Hargreaves Heap, 1989; Boudon, 1998, 2003; Echeverría and Álvarez Álvarez, 2008). The objective of this paper is not to point out this need but to draw a line of evolution for his most critical writings: those in which he separates himself from the mainstream economics paradigm. Simon's use of "maximization" to explain efficiency shows that the procedural approach serves the purpose to show that the process of rationality is imperfect when it tries to reach its goals. But rationality as it was defined and used in his first book also resembled the substantive rationality that he later criticized (Simon, 1976). Although Barros points it out this anachronism (2010), it is important to contextualize it within the whole scope of Simon's works and his empiricism.

\section{CONCLUSION}

There may not be a necessary connection between Simon's empiricism and his theories, but that this epistemological approach was present as part of his research methodology is undeniable. In Simon's philosophical fabric, his empiricism is the weft that unites all different concepts (or warps, to keep the metaphor) linked to the criticism of classical and neoclassical economics. This criticism is not the foundation of his work, but consequence of his positivist philosophy. His book $A B$ is the first step of this path. There, although he had not fully drawn yet his complete theory, he shared the idea that a realistic approach had to be imposed when explaining behavior from an economic perspective. There were several classical elements in his first work, but they eventually disappeared with the constant application of the above mentioned philosophical standards, which produce the complete rejection of the mainstream model of rationality and the implementation of a new paradigm within social sciences in relation to the rational behavior of subjects: the models of bounded and procedural rationality. Neither "bounded" nor "procedural" are terms that 
appeared in that book. The genesis of these concepts is found later (Simon, 1955, 1956), where Simon introduces the concept of "satisficing" opposed to "optimizing". Bounded rationality appeared for the first time in Models of Man (Simon, 1957), and his theory will be completed with the other concepts, implicitly used already, but not coined until the mid-seventies (Simon, 1976).

Although his epistemological view is constant during his career, it is left to clarify if Simon's empiricism is the only motivation that pushed him to develop his theories or, if this is not the case, in what way other factors contributed to his research. Herbert Simon not only introduced a new paradigm in rational theory, but also took the first steps towards an empirically based economics.

\section{REFERENCES}

Álvarez Álvarez, J. F. (2002). "El tejido de la racionalidad acotada y expresiva”. Manuscrito, XXV(2), 11-29.

Barros, G. (2010). "Herbert A. Simon and the concept of rationality: boundaries and procedures.” Revista de Economia Política, 30, 455-472.

Bartlett, R. V. (1989). "Rationality in administrative behavior: Simon, science, and public administration”. Public Administration Quarterly, 12(3), 301-314. http://doi.org/10.2307/40861424

Bonome, M. G. (2010). La racionalidad en la toma de decisiones: Análisis de la teoría de la decisión de Herbert A. Simon. Netbiblo.

Boudon, R. (1998). "Limitations of rational choice theory". The American Journal of Sociology, 104(3), $817-28$.

Boudon, R. (2003). "Beyond rational choice theory”. Annual Review of Sociology, 29, 1-21.

Brown, R. (2004). "Consideration of the origin of Herbert Simon's theory of "satisficing" (1933-1947)". Management Decision, 42(10), 1240-1256. http://doi.org/10.1108/00251740410568944

Byron, M. (1998). "Satisficing and optimality”. Ethics, 109(1), 67-93.

Callebaut, W. (2007). "Herbert Simon's silent revolution”. Biological Theory, 2(1), 76-86.

Chaserant, C. (2003) "Cooperation, contracts and social networks: From a bounded to a procedural rationality approach.” Journal of Management and Governance 7(2), 163-86. http://doi. org/10.1023/A:1023620127268

Crowther-Heyck, H. (2005). Herbert A. Simon: The Bounds of Reason in Modern America. Baltimore: Johns Hopkins University Press.

Cruise, P. (1997). "Are proverbs really so bad? Herbert Simon and the logical positivist perspective in American public administration". Journal of Management History (Archive), 3(4), 342-359. http:// doi.org/10.1108/13552529710191171

Dasgupta, S. (2003). “Multidisciplinary creativity: the case of Herbert A. Simon”. Cognitive Science, 27(5), 683-707.

Davis, C. R. (1996). “The administrative rational model and public organization theory”. Administration \& Society, 28(1), 39-60. http://doi.org/10.1177/009539979602800102

Dequech, D. (2001). "Bounded rationality, institutions, and uncertainty". Journal of Economic Issues, 35(4), 911-29.

Echeverría, J., \& Álvarez Álvarez, J. F. (2008). “Bounded rationality in social sciences.” In E. Agazzi (Ed.), Epistemology and the Social (pp. 173-91). Rodopi.

Geiger, N. (2015). The rise of behavioural economics: a quantitative assessment. Retrieved from http:// opus.uni-hohenheim.de/volltexte/2015/1084/

Gigerenzer, G. (2004). “Striking a blow for sanity in theories of rationality”. In J. G. March \& M. Augier (Eds.), Models of a Man: Essays in Memory of Herbert A. Simon (pp. 389-409). MIT Press.

González, W. J. (2004). Racionalidad, Historicidad y Predicción en Herbert A. Simon. Netbiblo. 
Hargreaves Heap, S. (1989). Rationality in Economics (First Edition). Blackwell Pub.

Heap, S. H., Hollis, M., Lyons, B., Sugden, R., \& Weale, A. (1992). The Theory of Choice: A Critical Guide (1st ed.). Wiley-Blackwell.

Jones, B. D. (1999). “Bounded rationality”. Annual Review of Political Science, 2--297.

Kotovsky, K. (1989). Complex Information Processing: The Impact of Herbert A. Simon : [21st Carnegie-Mellon Symposium on Cognition]. Psychology Press.

Mahoney, J. T. (2004). Economic Foundations of Strategy. SAGE.

Mingus, M. (2007). "Bounded rationality and organizational influence: Herbert Simon and the behavioral revolution”. In G. Morcol (Ed.), Handbook of Decision Making (pp. 61-79). CRC Press.

Muramatsu, R., \& Fonseca, P. (2012). "Freedom of choice and bounded rationality: a brief appraisal of behavioral economists' plea for light paternalism”. Revista de Economia Política, 32(3), 445 458. http://doi.org/10.1590/S0101-31572012000300006

Nieuwenburg, P. (2006). "Practical reasoning and action: Simon's administrative behavior in context". In G. Morcol (Ed.), Handbook of Decision Making (pp. 81-97). CRC Press.

Nozick, R. (1993). The Nature of Rationality. Princeton, N.J: Princeton University Press.

Ridley, C. E., \& Simon, H. A. (1938). "The criterion of efficiency". The ANNALS of the American Academy of Political and Social Science, 199(1), 20-25. http://doi.org/10.1177/000271623819900103

Sargent, T. J. (1993). Bounded Rationality in Macroeconomics. Oxford [England]: Clarendon Press.

Sent, E.-M. (1997). "Sargent versus Simon: bounded rationality unbound." Cambridge Journal of Economics, 21(3), 323-338.

Sent, E.-M. (2004). "Behavioral economics: how psychology made its (limited) way back into economics". History of Political Economy, 36(4), 735-760.

Sent, E.-M. (2005). “Simplifying Herbert Simon”. History of Political Economy, 37(2), 227-32. http:// doi.org/10.1215/00182702-37-2-227

Simon, H. A. (1997_1947). Administrative Behavior: A Study of Decision-Making Processes in Administrative Organizations (4th ed.). New York: Free Press.

Simon, H. A. (1955). "A behavioral model of rational choice". The Quarterly Journal of Economics, 69(1), 99-118.

Simon, H. A. (1956). "Rational choice and the structure of the environment." Psychological Review, 63(2), 129-38.

Simon, H. A. (1957). Models of man: social and rational; mathematical essays on rational human behavior in society setting. Wiley.

Simon, H. A. (1976). "From substantive to procedural rationality" Method and Appraisal in Economics (edited by S. J. Latsis, pp. 129-48). New York: Cambridge University Press.

Simon, H. A. (1982). Models of Bounded Rationality (Vol. 2). Cambridge, Mass: MIT Press.

Simon, H. A. (1983). Reason in Human Affairs. Stanford, Calif: Stanford University Press.

Simon, H. A. (1991). Models of My Life. New York: Basic Books.

Simon, H. A. (1997). Models of bounded rationality (Vol. 3). MIT Press.

Tolman, E. C. (1932). Purposive behavior in animals and men. The Century Co.

Waldo, D. (1948). The Administrative State: A Study of the Political Theory of American Public Administration. Transaction Publishers.

Weyland, K. G. (2007). Bounded Rationality and Policy Diffusion: Social Sector Reform in Latin America. Princeton, NJ: Princeton University Press. 